\title{
SGAT Confers Sitaram Rungta Memorial Award-2020 on Dr. Yamuna Singh
}

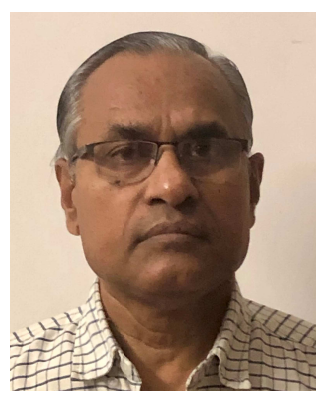

The Society of Geoscientists and Allied Technologists (SGAT), Bhubaneswar conferred Sitaram Rungta Memorial Award-2020 on Dr. Yamuna Singh in its $40^{\text {th }}$ AGM held on March 27, 2021 on Virtual Mode. Dr. Singh has over 35-year experience in exploration, research, resource evaluation and characterisation of Atomic and Rare Earth minerals. Currently, Dr. Singh is a visiting faculty at the Centre for Earth, Ocean and Atmospheric Sciences, University of Hyderabad.

Dr. Singh's long, methodical and meticulous exploration work led to the discovery of pegmatite hosted columbite, tantalite, beryl and monazite deposits at Kawadgaon in Bastar craton, Chhattisgarh. His work has also resulted in the Indian discovery of 5 Rare Ore minerals in Chittaurgarh Quartzite, Rajasthan; in Siwalik Sandstones at Romehra in Himachal Pradesh; and in the Granite at Akkavaram in Telangana. Dr. Singh has to his credit, reporting of the $1^{\text {st }}$ World occurrence of "Metamict Alluaudite" at Pisangarh, Rajasthan. He has made outstanding contributions in characterisation and genesis of uranium, thorium, rare metal and rare earth deposits of India.

For the above pioneering work in the fields of mineral exploration, ore characterisation, research and teaching, the SGAT, Bhubaneswar has conferred the "Sitaram Rungta Memorial Award-2020" on Dr Yamuna Singh.

DOI: $10.1007 / s 12594-021-1726-y$ 